LETTER TO JMG

\title{
Trinucleotide repeat expansion in SCA17/TBP in white patients with Huntington's disease-like phenotype
}

\author{
P Baver, F Laccone, A Rolfs, U Wüllner, S Bösch, H Peters, S Liebscher, M Scheible, \\ J T Epplen, B H F Weber, E Holinski-Feder, H Weirich-Schwaiger, D J Morris-Rosendahl, \\ J Andrich, $O$ Riess
}

J Med Genet 2004;41:230-232. doi: 10.1136/jimg.2003.015602

$\mathrm{H}$ untington's disease (HD) is characterized by movement abnormalities and psychiatric symptoms. Prominent features include choreiform movements, dysarthria, ataxia, depression, dementia, and personality changes. The disease usually manifests during the third or fourth decade of live and progresses with dysphagia and subsequent cachexia causing death some 20 years later. Neuropathologically, the disease is characterized by atrophy of the caudate and putamen and, to a lesser extent, of the cortex, globus pallidum, thalamus, subthalamic region, and substantia nigra. ${ }^{1}$

A CAG repeat expansion in the $H D$ gene resulting in an expanded polyglutamine chain in the huntingtin protein was identified as the major cause of HD. ${ }^{2}$ Phenocopies of HD have been described and designated as Huntington disease-like (HD-like). These disorders are genetically heterogeneous. In a consanguineous family of Saudi Arabian ancestry a juvenileonset choreiform disease resembling HD was described, inherited as an autosomal recessive trait. The chromosomal mapping might point to 4 p15.3, but still is controversial. ${ }^{3}{ }^{4}$ In senile chorea, CAG repeat expansions in the $H D$ gene have been excluded but a gene locus for this HD-like condition is not known. ${ }^{5}$ Several families have been reported with clinical features closely resembling HD and autosomal dominant inheritance. Among these, an early-onset non-progressive chorea with benign course has been associated with mutations in TITF-1 mapped to chromosome $14 \mathrm{q},{ }^{6}$ and a progressive form has been described in a Swedish family, and has been designated as HDL-1 localizing to chromosome 20p. ${ }^{7}$ Moore and co-workers and Laplanche and co-workers identified a 192-nucleotide insertion in the prion-protein gene (PRNP) that segregated with this phenotype in the family of Xiang and in one French family. ${ }^{89}$ More recently, a second family of African-American ethnicity with HD-like features showed repeat expansion in a gene mapping to chromosome 16q23 and the locus was designated HDL-2. ${ }^{10}$ Subsequently, a CAG/CTG repeat expansion in the junctophilin-3 gene was identified in this family and was shown to cosegregate with the disease in affected individuals. ${ }^{11}$ As HDL-1 is reported only anecdotally and HDL-2 could not be demonstrated in a large number of HD-like samples of white ancestry, ${ }^{12}{ }^{13}$ other loci are likely to contribute to the HD-like phenotype.

In addition to CAA/CAG repeat expansion in the TBP/SCA17 gene resulting in an expanded polyglutamine chain leads to spinocerebellar ataxia type 17 (SCA17). Phenotypically, beside cerebellar signs, psychiatric disturbances such as psychosis, depression, and dementia may be the first symptoms of the disease. Moreover, within SCAl7 families, affected members may present only with psychiatric symptoms while others show a cerebellar phenotype or dementia. Therefore, a remarkable overlap between SCAl7 phenotypes and HD-like phenotypes exists.
To investigate whether a CAA/CAG repeat expansion in the TBP/SCA17 gene may underlie the HD-like features in white patients, we analysed the CAA/CAG repeat in a group of 1.712 patients who were referred to DNA laboratories in Germany

\section{Key points}

- Expansion of a CAA/CAG trinucleotide repeat in the TATA-binding protein (TBP/spinocerebellar ataxia 17, SCA17) has recently been thought to be involved in autosomal dominant cerebellar ataxias. SCA17 is a rare cause of dominant cerebellar ataxia in white subjects with particular interesting clinical features. Beside cerebellar signs, psychiatric disturbances such as psychosis, depression, and dementia may be the first symptoms of the disease. Moreover, within SCA17 families, affected members may present only with psychiatric symptoms while others show a cerebellar phenotype or dementia. Therefore, a remarkable overlap between SCA17 phenotypes and Huntington's disease-like (HD-like) phenotypes exists.

- To investigate whether a CAA/CAG repeat expansion in the TBP/SCA17 gene may underlie the HD-like features in white patients we analysed the CAA/CAG repeat in a large group of 1712 patients who were referred for Huntington's disease (HD) testing to DNA laboratories in Germany and Austria. All patients were negative for expansions (had less than 36 CAG repeat units) in the $H D$ gene, thus excluding $H D$ as the cause of the symptoms.

- More than 45 CAA/CAG repeats in the TBP/SCA17 gene were detected in nine independent patients. Their phenotypes were indistinguishable from HD although cerebellar ataxia was noticed in all (6) patients for whom clinical data were available.

- In conclusion, repeat expansion in the TBP/SCA17 gene can be found in HD-like phenotypes. Particularly, the co-occurence of psychiatric and cerebellar symptoms in addition to choreiform disturbances in different members of a pedigree suggest this etiology.

Abbreviations: $A D C A$, autosomal dominant cerebellar ataxia; $H D$, Huntington's disease; HD-like, Huntington's disease-like; JPH3, Junctophilin-3 gene; PRNP, prion protein; SCA, spinocerebellar ataxia; TBP, TATA binding protein 
Clinical features of HD-like patients with CAG/CAA repeat expansion in the SCA17/TBP gene (one patient has been described in detail elsewhere ${ }^{16}$

\begin{tabular}{|c|c|c|c|c|c|c|c|c|c|}
\hline Pat ID & $\begin{array}{l}\text { Number of CAG/ } \\
\text { CAA repeats }\end{array}$ & Sex & Family history & $\begin{array}{l}\text { Age at } \\
\text { onset }\end{array}$ & $\begin{array}{l}\text { Presenting } \\
\text { symptom }\end{array}$ & Dementia & $\begin{array}{l}\text { Psychiatric } \\
\text { disturbances }\end{array}$ & Ataxia & Chorea \\
\hline 1 & $34 / 50$ & Male & $A D$ & $<45$ & Not reported & Not reported & Not reported & Not reported & Not reported \\
\hline 2 & $37 / 48$ & Female & Not reported & $<68$ & Not reported & Not reported & Not reported & Not reported & Not reportec \\
\hline 3 & $36 / 46$ & Female & $A D$ & 36 & Not reported & Yes & No & Yes & Yes \\
\hline 4 & $35 / 46$ & Male & Sporadic & 37 & $\begin{array}{l}\text { Psychiatric } \\
\text { disturbances }\end{array}$ & Not reported & Yes & Yes & Yes \\
\hline 5 & $36 / 50$ & Male & $A D$ & 32 & Dementia & Yes & Yes & Yes & Not reported \\
\hline 6 & $35 / 51$ & Female & $A D$ & 32 & Focal dystonia & Yes & Yes & Yes & No \\
\hline 7 & $37 / 48$ & Male & $A D$ & $35 ?$ & Dementia & Yes & No & Yes & No \\
\hline 8 & $35 / 46$ & Male & $A D$ & 38 & Dementia & Yes & No & Yes & Yes \\
\hline 9 & $40 / 52$ & Male & Not reported & 50 & Hyperkinesia & Not reported & Not reported & Not reported & Not reportec \\
\hline
\end{tabular}

$A D$ : autosomal dominant; "not reported" denotes that the clinical data accompanying the blood sample at the date of testing did not mention whether the clinical feature was present or not. As some DNA samples had been collected over 10 years ago, some patients were unavailable for a clinical update.

and Austria for testing the HD repeat expansion. ${ }^{14}$ All patients were referred by neurologists or psychiatrists. In this study we only included patients with fewer than 36 CAG repeat units in the HD-gene, thus excluding Huntington's disease as the genetic cause of the symptoms.

For SCA17, normal repeat numbers vary between 29 and 42. An intermediate range with reduced penetrance is assumed for 43-48 CAA/CAG repeats. ${ }^{15}$ In total we detected nine pathological CAA/CAG repeat expansions ranging from 46 to 52 repeats in the TBP/SCA17 gene in nine independent patients (table). From two patients clinical data were not accessible. Cognitive decline was reported as a prominent and early symptom in six patients. Two of these six patients had impressive cognitive impairment and PRNP gene mutations had previously been excluded. In five patients, ataxia in addition to choreiform movements had been observed prior to the exclusion of HD. Six patients had a family history of dementia, chorea, or ataxia and one patient was apparently sporadic.

Our findings are in accordance with a very recent report by Stevanin and co-workers (2003), who described repeat expansions in TBP/SCA17 gene in two sporadic French HDlike patients. ${ }^{17}$ Since at least $66 \%$ of our patients with pathological TBP/SCA17 repeats had positive family history, we therefore conclude that repeat expansions in the TBP/ SCA17 gene are causative for HD-like symptoms in addition to the well-recognized spinocerebellar ataxia phenotype. As cerebellar ataxia is not a common sign in Huntington's disease, ${ }^{1}$ this symptom should evoke special attention in patients with HD-like phenotype, eventually suggesting a TBP/SCA17 mutation. The TBP CAA/CAG repeat should also be tested in familial cases of HD-like symptoms with marked cognitive decline. In our large sample, CAA/CAG repeat expansions in the TBP/SCA17 gene represent a more common monogenic cause for a HD-like phenotype than HDL- 1 and HDL-2, and should therefore be considered in testing white choreatic patients for whom the HD mutation has been excluded.

\section{ACKNOWLEDGEMENTS}

We thank Willi Scheible for excellent technical support.

\footnotetext{
Authors' affiliations

P Baver, S Liebscher, M Schaible, O Riess, Department of Medical Genetics, University of Tübingen, Germany

F Laccone, Department of Human Genetics, University of Göttingen, Germany

A Rolfs, Department of Neurology, University of Rostock, Germany U Wüllner, Department of Neurology, University of Bonn, Germany S Bösch, Department of Neurology, University of Innsbruck, Austria H Peters, Department of Medical Genetics, Charité, Humboldt University Berlin, Germany
}

J T Epplen, Department of Human Genetics, Ruhr-University Bochum, Germany

B H F Weber, Institute of Human Genetics, University of Würzburg,

Germany

E Holinski-Feder, Medizinisch-Genetisches Zentrum, München,

Germany

H Weirich-Schwaiger, Institute of Medical Biology and Human Genetics, University of Innsbruck, Austria

D J Morris-Rosendahl, Institute of Human Genetics and Anthropology, University of Freiburg, Germany

J Andrich, Department of Neurology, Ruhr-University Bochum, Germany

Correspondence to: P Baver, MD, University of Tübingen, Department of Medical Genetics, Calwerstrasse 7, D 72076 Tübingen, Germany; peter.baver@med.uni-tuebingen.de

Received 17 October 2003

Revised 20 November 2003

Accepted 21 November 2003

\section{REFERENCES}

1 Huntington's disease. 3rd ed. Oxford: Oxford University Press, 2002.

2 The Huntington's Disease Collaborative Research Group. A novel gene containing a trinucleotide repeat that is expanded and unstable on Huntington's disease chromosomes. Cell 1993;72:971-83.

3 Kambouris M, Bohlega S, Al Tahan A, Meyer BF. Localization of the gene for a novel autosomal recessive neurodegenerative Huntington-like disorder to 4p15.3. Am J Hum Genet 2000;66:445-52.

4 Lesperance MM, Burmeister $M$. Interpretation of linkage data for a Huntington-like disorder mapping to 4p15.3. Am J Hum Genet 2000;67:262-3.

5 Shinotoh H, Calne DB, Snow B, Hayward M, Kremer B, Theilmann J, Hayden MR. Normal CAG repeat length in the Huntington's disease gene in senile chorea. Neurology 1994;44:2183-4.

6 Breedveld GJ, van Dongen JW, Danesino C, Guala A, Percy AK, Dure LS, Harper P, Lazarou LP, van der LH, Joosse M, Gruters A, MacDonald ME, de Vries BB, Arts WF, Oostra BA, Krude H, Heutink P. Mutations in TITF-1 are associated with benign hereditary chorea. Hum Mol Genet 2002;11:971-9.

7 Xiang F, Almqvist EW, Huq M, Lundin A, Hayden MR, Edstrom L, Anvret M, Zhang Z. A Huntington disease-like neurodegenerative disorder maps to chromosome 20p. Am J Hum Genet 1998;63:1431-8.

8 Laplanche JL, Hachimi KH, Durieux I, Thuillet P, Defebvre L, DelasnerieLaupretre N, Peoc'h K, Foncin JF, Destee A. Prominent psychiatric features and early onset in an inherited prion disease with a new insertional mutation in the prion protein gene. Brain 1999;122:2375-86.

9 Moore RC, Xiang F, Monaghan J, Han D, Zhang Z, Edstrom L, Anvret M, Prusiner SB. Huntington disease phenocopy is a familial prion disease. Am J Hum Genet 2001;69:1385-8.

10 Margolis RL, O'Hearn E, Rosenblatt A, Willour V, Holmes SE, Franz ML, Callahan C, Hwang HS, Troncoso JC, Ross CA. A disorder similar to Huntington's disease is associated with a novel CAG repeat expansion. Ann Neurol 2001:50:373-80.

11 Holmes SE, O'Hearn E, Rosenblatt A, Callahan C, Hwang HS, IngersollAshworth RG, Fleisher A, Stevanin G, Brice A, Potter NT, Ross CA, Margolis RL. A repeat expansion in the gene encoding junctophilin-3 is associated with Huntington disease-like 2. Nat Genet 2001;29:377-8.

12 Bauer I, Gencik M, Laccone F, Peters H, Weber BHF, Holinski Feder E, Weirich H, Morris-Rosendahl DJ, Rolfs A, Gencikova A, Baver P, Wenning GK, Epplen JT, Holmes SE, Margolis RL, Ross CA, Riess O. Trinucleotide repeat expansions in the junctophilin-3 gene are not found in Caucasian patients with a Huntington's disease like phenotype. Ann Neurol 2002;51:662. 
13 Stevanin G, Camuzat A, Holmes SE, Julien C, Sahloul R, Dode C, HahnBarma V, Ross CA, Margolis RL, Durr A, Brice A. CAG/CTG repeat expansions at the Huntington's disease-like 2 locus are rare in Huntington's disease patients. Neurology 2002:58:965-7.

14 Laccone F, Engel U, Holinski-Feder E, Weigell-Weber M, Marczinek K, Nolte D, Morris-Rosendahl DJ, Zuhlke C, Fuchs K, Weirich-Schwaiger H Schluter G, von Beust G, Vieira-Saecker AM, Weber BH, Riess O. DNA analysis of Huntington's disease: five years of experience in Germany, Austria, and Switzerland. Neurology 1999;53:801-6.
15 Rolfs A, Koeppen AH, Baver I, Baver P, Buhlmann S, Topka H, Schöls L, Riess $O$. Clinical features and neuropathology of autosomal dominant spinocerebellar ataxia (SCA17). Ann Neurol 2003;54:367-75.

16 Zühlke C, Gehlken U, Hellenbroich Y, Schwinger E, Bürk K. Phenotypical variability of expandedalleles in the TATA-binding protein gene. JNeurol 2003:250:161-3.

17 Stevanin G, Füigasaki H, Lebre AS, Camuzat A, Jeannequin C, Dode C, Takahashi J, San C, Bellance R, Brice A, Durr A. Huntington's disease-like phenotype due to trinucleotide repeat expansions in the TBP and JPH3 genes. Brain 2003;126:1599-603. 